\title{
YOUTH CULTURE DAN GAYA BUSANA: \\ HIPER-REALITAS PEKERJA MUDA PEREMPUAN TERHADAP PRODUK FASHION BERMEREK DI JAKARTA
}

\begin{abstract}
Abstrak
Fashion menjadi bagian yang tidak dapat dilepaskan dari penampilan dan gaya hidup keseharian seseorang. Saat ini, fashion bukan lagi sekadar pemenuhan kebutuhan untuk menutupi dan melindungi tubuh dalam beraktifitas sehari-hari. Fashion dapat menjadi alat komunikasi identitas, ekspresi diri, yang membedakan individu satu dengan lainnya. Inilah beberapa alasan pemilihan fashion bermerek bagi para pekerja muda perempuan di Jakarta. Penelitian ini dilakukan untuk memahami bagaimana hiper-realitas pekerja muda perempuan memaknai produk fashion bermerek yang mereka kenakan, dan nilai-nilai apa saja yang dipertukarkan. Penelitian ini menemukan adanya kondisi hiper-realitas yang dibangun oleh para pekerja muda perempuan dalam memaknai produk fashion bermerek yakni terbentuknya pseudo-power. Mereka memperoleh kekuasaan semu saat mengenakan produk fashion bermerek. Kekuasan semu yang didapat ada tiga; superior, trendsetter dan dominator. Hiperrealitas tersebut juga terkait dengan nilai-nilai sosial yang dipertukarkan berupa pujian dari orang lain, rasa percaya diri, image diri, dan kepuasan diri.
\end{abstract}

Kata Kunci : Fashion, gaya hidup, hiper-realitas, kekuasaan semu

\begin{abstract}
Fashion has practically become an integral part of anybody's life style on day-to-day basis. Nowadays, it is no longer a mere cloth covering her/his body to protect it from head and cold. Furthermore, it has transformed to be a tool of self-expression, self-image and selfidentity of the person putting it on. By fashion here to means a valuable imported branded cloth. Against this backdrop, the research attempts to explicate why the informant (Jakartan young female professional) do so at the expense of meeting their daily basic neeeds. What values (power) they want to obtain by wearing those branded clothes.This qualitative study also tries to explore how they make sense of putting on those imported clothes. After collecting data through observation and interview, the study found that they did so in return for exchange value; psedou power which fall into three categories; superior, trendsetters and dominator. They were captuted by what it is as hyper-reality. Added to that, they did so in order to meet social values from their close social circle. Those values are such as a praise from others, self-confidence, self-image, and self-satisfaction.
\end{abstract}

Keywords: Fashion, lifestyle, hyper-reality, pseudo-power

\section{Pendahuluan}

Saat ini dunia fashion mengalami perkembangan yang sangat pesat, ditandai dengan munculnya berbagai macam mode produk fashion dari yang tidak bermerek sampai yang bermerek. Fashion bermerek 
didefinisikan sebagai produk-produk pakaian dengan label atau logo tertentu yang popular dalam suatu budaya. Rouse menyatakan bahwa label dan logo adalah salah satu cara untuk menunjukkan daya beli seorang konsumen (dalam Barnard 2009:158). Label serta merek pakaian terkenal dengan harga yang mahal dapat membawa efek prestisius dan meneguhkan posisi sosial dan ekonomi yang tinggi bagi yang mampu membelinya karena komunikasi visual melalui fashion dapat mengkespresikan "lebih" dibandingkan komunikasi verbal (Barnard, 2009: 25).

Orang-orang yang cenderung untuk peduli dengan fashion, kebanyakan adalah para pekerja muda perempuan. Karena lingkungan sosial menuntut mereka untuk tampil "lebih" dalam hal berpakaian. Fashion menjadi daya tarik bagi pekerja muda karena mereka menyadari penampilan fisik yang menarik sangat membantu statusnya dalam pekerjaannya, (Hurlock, 1996). Pekerja muda perempuan didefinisikan atas dasar batasan usia pemuda. Menurut Undang-Undang Republik Indonesia Nomor 40 Tahun 2009, tentang Kepemudaan: Pemuda adalah warga negara Indonesia yang memasuki periode penting pertumbuhan dan perkembangan yang berusia 16 (enam belas) sampai 30 (tiga puluh) tahun. Anak muda memang bukan sekadar batasan usia, namun merupakan sebuah kategori sosial yang pemaknaannya dibentuk berdasarkan konteks tertentu, baik sosial, politik, budaya, ekonomi dan sebagainya. Di Indonesia, biasanya usia 22 Tahun ratarata baru menyelesaikan pendidikan $\mathrm{S} 1$ dan memulai bekerja. Sedangkan menurut Wittasari (2008:68-72), para pekerja muda perempuan adalah mereka yang berusia antara usia 25-35 tahun, umumnya mereka sudah bekerja dan memiliki penghasilan sendiri sehingga cenderung untuk mampu membeli produk-produk pakaian bermerek yang mereka inginkan. Studi yang dilakukan Markplus juga mengatakan bahwa youth (umur 19-35 tahun) merupakan kategori penting dalam aspek marketing untuk meraih mind share suatu produk. Pada survei yang dilakukan tahun 2012, menyatakan bahwa total pengeluaran youth paling tertinggi ada pada belanja fashion, kemudian entertainment dan saving (MarkPlus Insight Youth Survey, 2012).

Penelitian sebelumnya yang dilakukan Savitrie (2008) mengemukakan bahwa produk mass fashion dari segmen kiblat luar paling banyak dikonsumsi, merek-merek seperti Mango, Zara, seringkali disebut. Poppy Dharsono (dalam Savitrie, 2008) membagi industri fashion menjadi 4 segmen, segmen Tanah Abang, segmen berkiblat ke desainer luar 
seperti Mango, Zara, GAP, Hammer. Segmen fashion desainer dan segmen temporary fashion. Pergantian musim (season) di toko-toko ritel fashion di Jakarta jauh lebih cepat mencapai 4-6 bulan sekali dan pemasukan barang mencapai 8-10 sekali tiap bulan. Dan koleksi terbaru muncul pertama kali di Jakarta, sehingga Jakarta menjadi acuan fashion pertama oleh daerah-daerah lain. Responden juga mengaku bahwa majalah sangat mempengaruhi mereka dalam menentukan pilihan fashion. Majalah yang paling banyak disebut adalah Go Girl, Dewi, Bazaar, Femina, Her World dan Gadis.

Penelitian lain yang dilakukan oleh Angraini (2012:11) menyebutkan bahwa alasan perempuan dalam membeli fashion bermerek adalah untuk membangun identitas yang melekat pada diri mereka antara lain:wanita yang berkelas, elit dan berselera tinggi, fashionable, mengikuti mode dan ingin menjadi trend setter atau ingin menunjukkan identitas diri mereka sebagai wanita karier yang mapan. Sedangkan menurut Puspita dan Nashori, (2009:16) melalui hasil penelitiannya menunjukkan tingkat kepercayaan diri berhubungan erat dengan minat membeli barang-barang bermerek artinya jika tingkat kepercayaan diri tinggi, maka minat untuk membeli barang-barang bermerek juga meningkat, (Puspita \& Nashori, 2009:16).

Merujuk pada pemikiran Baudrillard (1994) fenomena diatas disebut simulasi. Dimana simbol menjadi semakin terpisah dari obyek yang direpresentasikan (Littlejohn, 2002:307). Pakaian bermerek tidak lagi merepresentasikan pakaian sebagai penutup tubuh. Tetapi merek yang ada di pakaian tersebut membawa makna baru setiap mengalami reduplikasi. Fashion telah mengalami era simulasi, dimana sebuah tanda (fashion bermerek) tidak lagi merepresentasikan realitas pakaian itu sendiri. Ini berarti berdasarkan nilai gunanya, pakaian memiliki nilai untuk melindungi tubuh dari berbagai gangguan. Tetapi pada perkembangan kapitalisme modern, nilai pakaian tersebut telah bergeser menjadi nilai tukar. Pakaian yang sejatinya sebagai penutup tubuh telah dipertukarkan dengan identitas perempuan mapan dan kepercayaan diri. Mengacu Marx, terdapat dua nilai-tanda dalam sejarah kebudayaan manusia yakni, nilaiguna (use-value) dan nilai-tukar (exchange-value). Nilai-guna merupakan nilai asli yang secara alamiah terdapat dalam setiap objek. Berdasarkan manfaatnya, setiap objek dipandang memiliki guna bagi kepentingan manusia. Nilai inilah yang mendasari bangunan 
kebudayaan masyarakat awal. Selanjutnya dengan perkembangan kapitalisme, nilai dasar tersebut telah beralih menjadi lahir nilai baru yakni nilai-tukar. Nilai-tukar dalam masyarakat kapitalis memiliki kedudukan penting karena dari sanalah lahir konsep komoditi. Dengan konsep komoditi, segala sesuatu dinilai dan diukur berdasarkan nilai-tukarnya (Hidayat 2008). Berkaitan dengan gaya berbusana, Anggraini (2012:4) menyebutkan para pekerja muda khususnya perempuan lebih senang berbelanja barang bermerek meskipun kualitasnya terkadang tidak lebih baik daripada barang dengan merek yang tidak begitu terkenal. Hal ini karena merek pakaian termasuk citra perseptual yang turut membangun gaya hidup dan digunakan oleh pemakainya untuk menyatakan dirinya, (Piliang, 2011:75). Dengan demikian dapat disimpulkan bahwa seseorang membeli produk dengan merek tertentu dengan tujuan untuk menutupi tubuh mereka tetapi lebih dimaksudkan untuk ekspresi diri pribadi mereka.

Merek (brand) diartikan sebagai gambaran produk atau jasa tertentu yang mana konsumen dapat mengetahui produk tersebut dengan mengidentifikasi nama, logo, desain, atau slogan (Brick Marketing www.brickmarketing.com). Peneliti mengkategorikan merek fashion merujuk pada segmen fashion yang berkiblat ke desainer luar (Savitrie, 2008) dan merek tersebut disebutkan dan/atau beriklan di majalah fashion franchise. Di Indonesia, produk ini seringkali dijual di pusat perbelanjaan (mall), ataupun department store besar seperti Senayan City, Pondok Indah Mall, Plaza Indonesia, Sogo, Metro dan sebagainya. Beberapa produk fashion bermerek yang dimaksud antara lain Zara, Mango, GAP, Hammer, Louis Vuitton, Channel, Hermes, NyLA, Charles \& Keith, Chloe, dan lain-lain.

Pekerja muda perempuan sebagai subyek penelitian dengan membatasi definisi pekerja muda perempuan adalah mereka yang berusia antara usia 22-35 tahun. Asumsi ini diambil berdasarkan Wittasari (2008:68-72), yang mendefinisikan pekerja muda perempuan adalah mereka yang berusia antara usia 2535 tahun, umumnya mereka sudah bekerja dan memiliki penghasilan sendiri sehingga cenderung untuk mampu membeli produkproduk pakaian bermerek yang mereka inginkan. Diambil batasan usia 22 tahun karena di Indonesia, rata-rata telah menyelesaikan studi sarjana (S1) dan mulai bekerja.

Fashion menjadi bagian yang tidak dapat dilepaskan dari penampilan dan gaya keseharian seseorang, terutama 
perempuan. Lebih dari itu fashion dapat menjadi sebuah alat komunikasi untuk menyampaikan sebuah identitas, baik itu identitas pribadi, nasional dan kultural pemakainya (Ibrahim, 2007:243). Hal ini menunjukkan bahwa seseorang akan dinilai lewat pakainnya, serta bagaimana bersikap, kelas sosial, keseriusan atau kesantaian, keglamoran atau keeleganan. Tidak hanya itu, bahkan kreatifitas seseorang juga akan dilihat dari sense of style dalam berpakaian. Fashion, makanyatelah menjadi sebuah fenomena komunikatif dan kultural yang digunakan oleh suatu kelompok untuk mengkonstruksi dan mengkomunikasikan identitasnya. Ini karena karena fashion merupakan cara komunikasi nonverbal untuk memproduksi serta mempertukarkan makna dan nilai-nilai yang ingin disampaikan melalui apa yang ditampilkan. Dengan kata lain, Fashion merupakan bentuk ekspresi individu seseorang yang diarahkan untuk mengkomunikasikan bahwa individu satu berbeda dengan lainnya. Tidak hanya itu, fashion juga dimaksudkan untuk mendefinisikan peran sosial yang dimiliki seseorang. Pakaian yang dikenakannya sebagai penciri pribadi memungkinkannya untuk dapat melakukan interaksi sosial yang berbeda pula. Ini karena Fashion atau pakaian juga kerap digunakan untuk menunjukan nilai ekonomi atau status seseorang (Nugraha, 2012:6).

Selain sebagai penyampai identitas seseorang, Fashion juga merupakan mekanisme atau ideologi yang berlaku dalam dunia modern, wujud dari sebuah entitas yang berhubungan dengan hasrat untuk tampil berbeda (Svendsen, 2006:11). Trend fashion yang berlaku menyusupkan ideologi pemakainya, menanamkan cara pandang untuk melihat fashion sebagai simbol gaya hidup dan merek adalah bagian dari fashion. Dalam aspek komunikatif dan fungsional, fashion tidak hanya sekedar sebagai sebuah karya seni akan tetapi juga dipergunakan sebagai simbol untuk membaca status seseorang dan cerminan budaya yang dibawa (Nugraha, 2012:6). Barthes (1990:12) menyebutkan, fashion adalah sebuah sistem tanda (symbol), sehingga dapat dikatakan bahwa cara berpakaian merupakan sebuah simbol untuk menunjukkan jati diri atau nilai budaya yang dianut oleh seseorang dan fashion sesungguhnya dapat berbicara tentang sesuatu yang sangat erat dengan diri seseorang.

Dengan demikian, pakaian telah beralih fungsi menjadi ekspresi pribadi. Seperti ungkapan yang jamak ditemukan seperti "I am what I wear" atau "You are what you put on". Atau meminjam 
pernyataan Umberto Eco (1979:5), “I speak through my cloth", Aku berbicara lewat pakaianku. Pakaian merupakan alat semiotika atau sarana komunikasi dalam masyarakat, maka masyarakat sadar atau tidak sadar bisa menilai kepribadian seseorang dari apa yang dipakainya. Hal ini seperti yang diyakini Baudrillard bahwa simbol menjadi semakin terpisah dari obyek yang direpresentasikan (Littlejohn :2002 :307). Hari ini, dunia berada pada era simulasi (simulation), dimana sebuah tanda tidak lagi merepresentasikan realitas. Tetapi tanda tersebut diciptakan untuk realitas (Littlejohn :2002:308). Realitas telah melebur menjadi satu dengan tanda, citra dan model-model reproduksi. Dengan demikian, tidak mungkin lagi ditemukan referensi yang real yang dapat membedakan antara representasi dan realitas, citra dan kenyataan, tanda dan ide, serta yang semu dan yang nyata. Yang ada hanyalah campur aduk diantara semuanya (Hidayat :2008).Simulasi adalah era yang dibangun oleh model-model realitas tanpa asal-usul; sebuah dunia hiper-real. Teritori tidak lagi hadir sebelum peta, atau yang membentuknya. Sebaliknya, petalah yang hadir sebelum teritori sebagai sebuah acuan simulacra. Singkat kata, petalah yang membentuk teritori (Baudrillard:1994).
Berdasarkan latar belakang tersebut, tidak heran, jika realitas simulasi yang menonjol adalah dunia shopping mall. Lokasi ini melebihi dari sekedar tempat belanja, tapi adalah adalah sebuah dunia simulasi yang menampilkan realitasrealitas buatan yang bersifat semu, dimana justru dalam kesemuannya itulah tempat tersebut lebih menyenangkan dibanding realitas sebenarnya (Piliang dalam Hidayat, 2008). Dunia barang dan kebutuhan merupakan histeria yang menyebar ke semua orang. Kebutuhan tidak pertama-tama akan suatu obyek, tetapi kebutuhan untuk tampil beda (hasrat akan makna sosial), maka tidak akan pernah ada kepuasan penuh. Jadi bukan fungsi kebutuhan seseorang yang menentukan, tetapi fungsi sosial, komunikasi, distribusi nilai melalui tatanan tanda. Bukan pertama-tama fungsi kenikmatan, tetapi lebih pada fungsi koleltif (Haryatmoko : 2010:23).

Sepadan dengan shopping Mall adalah Disneyland yang menurut Baudrillard sebagai model sempurna orde simulacra. Tahap ini merupakan permainan pertama dari ilusi dan khayalan (Baudrillard, 1994:12). Disneyland terus mengalami duplikasi hingga tidak diketahui lagi mana yang hasil duplikasi dan mana yang asli. Simulacra tidak memiliki acuan, ia adalah duplikasi dari 
duplikasi, sehingga perbedaan antara duplikasi dan yang asli menjadi kabur. Dalam ruang ini tidak dapat lagi dikenali mana yang asli dan mana yang palsu, mana hasil produksi dan mana hasil reproduksi, mana objek dan mana subjek, atau mana penanda dan mana petanda (Hidayat, 2008). Nah, silang sengkarut tanda ini akan menghasilkan simulacrum atau gambaran suatu obyek yang tidak ada hubungannya dengan realitas tersebut. Simulacrum menanamkan suatu gambaran yang diterima begitu saja seolah-olah begitu adanya. Perbedaan jelas antara simulasi, simulacra, dan simulacrum dapat dijelaskan sbagai berikut. Simulasi merupakan sebuah tiruan dari sesuatu, objek/keadaan dimana masih mudah/bisa dibedakan atau ditemukan perbedaannya antara yang asli dan palsu/mana realitas sebenarnya dan mana realitas buatan. Ketika sebuah simulasi bercampur dengan kenyataan sebenarnya, direpresentasikan dan dibuat se-nyata mungkin serta melibatkan pengalaman/sisi emosi dari masyarakat maka akan membentuk sebuah simulacra. Simulacra merupakan "simulasi" yang lebih advance yang mencapai sebuah titik dimana sebuah realita menjadi sulit bahkan tidak bisa dibedakan lagi mana yang kenyataan sebenarnya dan mana kenyataan yang dikonstruksikan (dibentuk). Keadaan tersebut diistilahkan dengan Hiper-real atau realitas yang berlebih. Hiper-realitas adalah sebuah gejala di mana banyak bertebaran realitas-realitas buatan yang bahkan nampak lebih real dibanding realitas sebenarnya (Hidayat, 2008). Singkat kata, hiper-realitas adalah suatu keadaan nyata tanpa realitas (Baudrillard, 1994:1).

Lebih jauh, realitas buatan (citracitra) kini tidak lagi memiliki asal-usul, referensi ataupun kedalaman makna. Tokoh Rambo, boneka Barbie, Jurrasic Park, atau Star TrekVoyager yang merupakan citra-citra buatan adalah realitas tanpa referensi, namun nampak lebih dekat dan nyata dibanding keberadaan tetangga kita sendiri. Dalam kondisi seperti ini, realitas, kebenaran, fakta dan objektivitas kehilangan eksistensinya. Hiper-realitas adalah realitas itu sendiri (Baudrillard dalam Hidayat, 2008). Walaupun telah banyak penelitian dalam konteks media massa maupun budaya populer di Indonesia yang menggunakan konsep semiotika Baudrillard, pada penelitian ini akan mengeksplorasi lebih dalam mengenai simulasi, simalucra, simulacrum dan hiperrealitas dalam dunia fashion. Dimana fenomena Hermes, Louis Vuitton, Channel, Zara dan merek-merek lainnya mengalami proses simulasi yang sama 
dengan boneka Barbie, Rambo dan Disneyland. Nah, dalam masyarakat konsumsi menurut Baudrillard, orang tidak hanya mengonsumsi barang, tetapi juga jasa dan hubungan antar manusia. Masyarakat konsumsi diidentikkan dengan pertumbuhan masyarakat yang dalam prosesnya merupakan lingkaran setan pertumbuhan yang dihubungkan dengan pemborosan. Terkait konteks tersebut, pandangan moral tentang pemborosan sebagai disfungsi diambil kembali menurut fungsi-fungsi yang sebenarnya (Baudrillard, 2009: 31-33).

Konsumsi dalam perspektif Baudrillard dipahami sebagai sistem tanda berdasarkan penafsiran terhadap tanda (simbol-simbol) sosial, antara lain:

\section{Kerangka konsep}

Konsep pemaknaan dalam penelitian ini merujuk pada obyek fashion sebagai simbol komunikasi. Fungsi pakaian menurut hierarki kebutuhan Maslow sebenarnya adalah fungsi yang paling dasar yaitu physiological needs (kebutuhan fisiologis) karena diperlukan untuk perbedaan kelas sosial, gender, dan ras. Baudrillard melihat bahwa dalam masyarakat konsumsi hadir dari sebuah kebutuhan yang berlebih, alih-alih sebuah over-produksi. Masyarakat konsumsi mengalami krisis terlebih pada ketidakmampuan produksi untuk mengimbangi pertumbuhan "kebutuhan" yang terjadi secara besar-besaran. Begitu juga dengan nilai lebih dari produksi yang tampak diakulturasikan Baudrillard menjadi konsep nilai lebih konsumsi, dimana hadir distribusi kekayaan kepada komunitas yang lebih luas. Kebutuhan dan kepuasan konsumen merupakan kekuatan produktif yang dipaksakan dan disesuaikan (Baudrillard, 2011: 92-93).

melindungi fisik dari panas dan dingin yang berlebihan. Namun konsumsi fashion tidak hanya dimaknai sebagai pemenuhan kebutuhan hidup semata. Berdasarkan penjelasan diatas, maka dapat digambarkan kerangka konseptual dalam penelitian ini adalah sebagai berikut: 


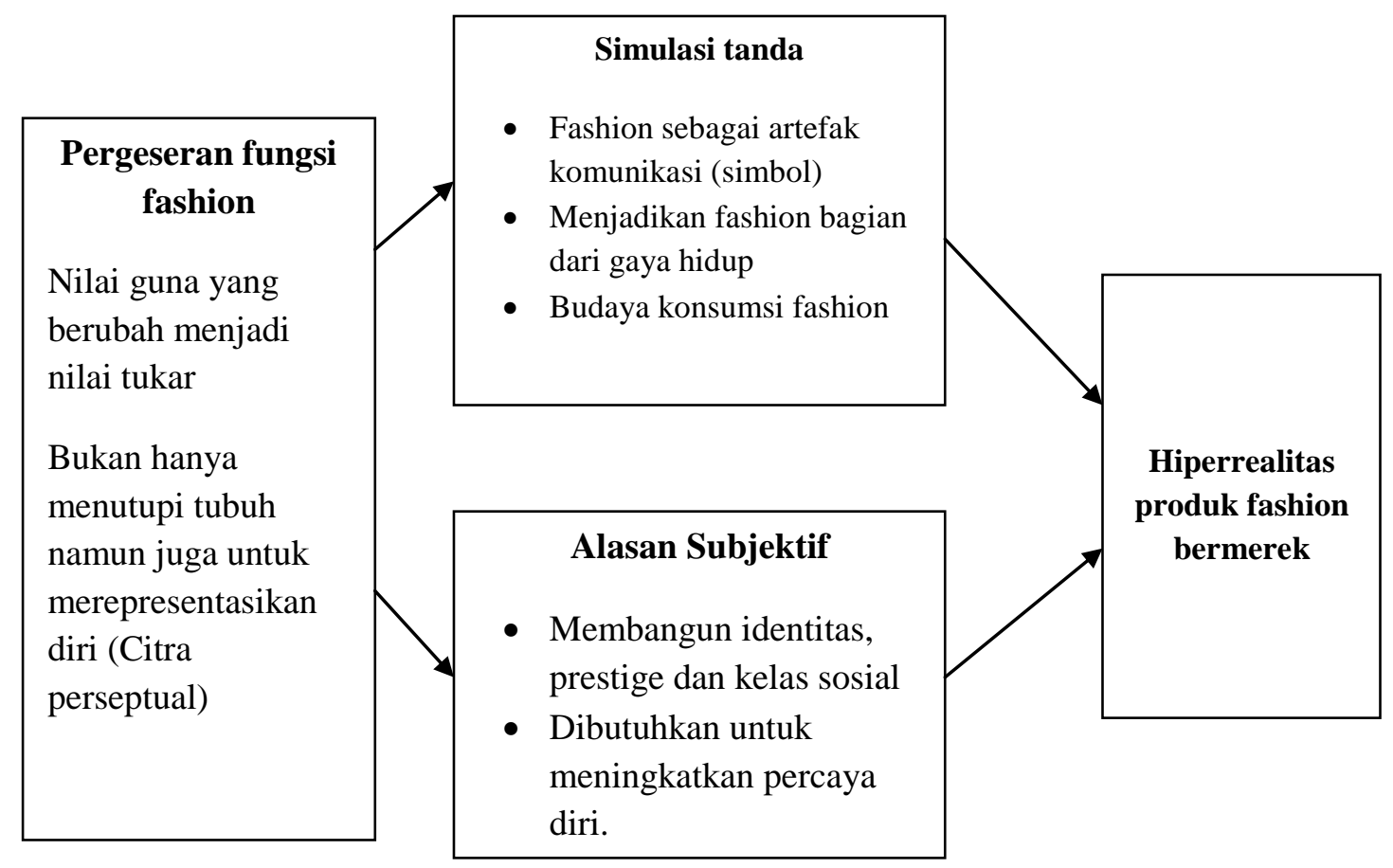

Fashion dapat menjadi sebuah alat komunikasi untuk menyampaikan sebuah identitas, baik itu identitas pribadi, nasional dan kultural pemakainya (Ibrahim, 2007:243). Dengan demikian saat ini fashion telah menjadi bagian dari gaya hidup dan membeli barang-barang fashion bermerek dianggap sebagai hal

\section{Metodologi penelitian}

Penelitian ini menggunakan paradigma critical constructivism karena bertujuan memahami pemaknaan perempuan pekerja muda terhadap produk fashion bermerek yang merupakan hasil konstruksi pihak yang berkuasa,dalam hal ini kaum kapitalis. Penelitian ini menggunakan pendekatan kualitatif dengan tipe penelitian constructivism wajar. Dengan membeli barang-barang fashion bermerek maka para wanita pekerja dianggap sebagai seseorang yang memiliki status ekonomi yang tinggi. Hal tersebut berkaitan dengan peningkatan rasa percaya diri seseorang dalam lingkungannya.

dengan menambahkan elemen kritis didalamnya. Hal ini muncul karena fenomena yang diteliti dikontruksi secara sosial. Realitas dibangun dari asumsi dan pandangan kelompok sosial yang mengkonstruksikannya (Patton,2002:100).

Metode pengumpulan data yang digunakan dalam penelitian ini adalah indepth interview dan observasi. In-depth interview atau wawancara mendalam 
digunakan untuk menggali persepsi dan pengalaman pribadi informan. Metode ini juga memungkinkan peneliti memperoleh insight dalam konteks sosial budaya kehidupan seseorang. Sedangkan observasi digunakan untuk mengobservasi apa yang orang lakukan dan bagaimana mereka bertindak dan berinteraksi dalam situasi sosial (Hennink, Hutter, \& Bailey, 2011). Wawancara mendalam maupun observasi akan memberikan informasi yang saling melengkapi untuk menjawab rumusan masalah. Kedua metode ini digunakan agar memperoleh pemahaman secara keseluruhan pemaknaan perempuan pekerja terhadap produk fashion bermerek yang mereka gunakan.

Populasi dari penelitian ini adalah seluruh pekerja muda perempuan di Jakarta yang mengkonsumsi produk fashion bermerek. Karena populasi tersebut tidak memiki kerangka sampel maka pemilihan informan menggunakan teknik purposive (Hadi, 2009). Purposive sampling sesuai digunakan untuk menyeleksi kasus tertentu yang informatif. Lebih spesifik metode pemilihan informan yang digunakan adalah metode criterion sampling. Patton menyatakan bahwa metode criterion adalah metode yang mempertimbangkan seluruh kriteria yang telah ditentukan sebelumnya agar didapat informan yang meyakinkan secara kualitas(2002:238). Teknik ini digunakan untuk menyeleksi informan yang sulit terjangkau secara populasi. Berdasarkan hal tersebut, maka dalam penelitian ini ditetapkan minimal ada 3 informan, dengan kriteria yaitu masing-masing informan merupakan perempuan pekerja muda dalam rentang umur 22-35 tahun (Wittasari, 2008), menghabiskan minimal $18 \%$ dari gajinya untuk pakaian (Rema, 2013), dan memakai pakaian atau fashion bermerek segmen berkiblat ke luar negeri seperti merek Mango, Zara, Gap dan sebagainya (Savitrie, 2008). Seleksi informan dilakukan sendiri oleh peneliti dengan pengamatan berdasarkan kriteria yang telah ditetapkan. Sehingga, memungkinkan informan merupakan orang-orang yang telah dikenal peneliti.

Jumlah 3 orang informan ini diharapkan dapat memberikan gambaran dan pemahaman yang lebih mendalam dan luas terhadap pemaknaan profuk fashion bermerek. Jumlah informan berhenti pada 3 orang karena data yang telah didapatkan mencapai titik jenuh. Artinya, hampir semua informan mengungkapkan hal-hal yang sama mengenai pemaknaan fashion dan hiperealitas yang mereka ciptakan terhadap fashion yang mereka gunakan. 
Penilaian goodness criteria untuk penelitian kualitatif dilakukan dengan menguji reliabilitas dan validitas. Pengujian reliabilitas dengan cara menilai konsistensi penelitian terhadap teori yang digunakan untuk analisis, dan konsisten terhadap metodologi yang digunakan. Sedangkan pengujian validitas dilakukan dengan melihat refleksi otentik, yaitu adil, jujur dan berimbang dalam analisis (Neuman, 2006). Penelitian tersebut dapat dikatakan valid karena berimbang dalam analisis yang tidak menyalahkan atau mengevaluasi pemaknaan informan.

\section{Temuan penelitian}

Nara sumber dalam penelitian ini terdiri dari 3 orang perempuan yang bekerja kantoran dan termasuk kategori youth (19-35 tahun). Nara sumber diketahui sering membeli dan memakai produk fashion bermerek dalam kesehariannya. Hal ini terlihat dari kebiasaan berbelanja (shopping habit) para nara sumber . Semua nara sumber berbelanja pakaian di pusat perbelanjaan modern (mall) yang tergolong kelas atas seperti FX Sudirman, Pondok Indah Mall, Senayan City dan lain-lain. Harga produk yang dibeli berkisar antara Rp 150.000 Rp $\quad 1.500 .000$ setiap item. Cara pembayaran semua nara sumber menggunakan uang tunai (cash) dan 2 nara sumber yang menggunakan kartu kredit. Fashion bermerek yang paling sering dikonsumsi adalah Zara, menyusul Mango, Charles\&Keith, Andre Valentino dan The Executive. Nara sumber memperoleh pengetahuan fashion bermerek tersebut melalui majalah fashion, seperti Cosmopolitan, Lux, Cleo, dan Laika. Selain itu, juga melalui blog fashion, foto-foto Instagram dan website fashion yang ada di internet. Frekuensi membeli produk fashion bermerek ratarata seminggu sekali, tetapi untuk mencari tahu tentang berita fashion, baik itu melaui majalah maupun browsing di internet, nara sumber melakukannya setiap hari. Konsumsi produk fashion bermerek menciptakan realitas yang berlebihan atau hiperrealitas pada diri pemakainya. Pakaian atau fashion tidak lagi dianggap sebagai pakaian itu sendiri. Terlebih pakaian berlabel merek terkenal akan memberikan nilai tambah kepada di pemakai. Berikut ini adalah hasil analisis mengenai produk fashion bermerek dengan nilai-nilai yang ditukarkan dan hiperrealitas yang dibangun oleh masingmasing nara sumber 


\begin{tabular}{|c|c|c|c|}
\hline & Nara sumber 1 & Nara sumber 2 & Nara sumber 3 \\
\hline LatarBelakang & $\begin{array}{l}28 \text { th, S2, PNS, } \\
\text { Menikah punya } 1 \\
\text { anak }\end{array}$ & $\begin{array}{l}25 \text { th, S1, Staff Media } \\
\text { Parpol, lajang }\end{array}$ & $\begin{array}{l}26 \text { th, S1, Legal Officer, } \\
\text { lajang }\end{array}$ \\
\hline Motivasi & $\begin{array}{l}\text { Hobi ke mall, } \\
\text { kebutuhan, suka } \\
\text { berbelanja, } \\
\text { hiburan(Faktor } \\
\text { Internal) }\end{array}$ & $\begin{array}{l}\text { Tuntutan lingkungan } \\
\text { pekerjaan (Faktor } \\
\text { eksternal) hiburan, } \\
\text { untuk koleksi, suka } \\
\text { berbelanja (faktor } \\
\text { internal) }\end{array}$ & $\begin{array}{l}\text { Impulsif, hiburan, } \\
\text { menghabiskan uang, suka } \\
\text { berbelanja, mempertahankan } \\
\text { image (Faktor internal). } \\
\text { Tuntutan pekerjaan (faktor } \\
\text { eksternal). }\end{array}$ \\
\hline $\begin{array}{l}\text { Shopping } \\
\text { habit }\end{array}$ & $\begin{array}{l}\text { High end mall, } \\
\text { seminggu sekali, tas, } \\
\text { baju, sepatu, } \\
\text { kerudung, }>400 \text { ribu, } \\
\text { cash, mengutamakan } \\
\text { kualitas dan } \\
\text { originalitas. } \\
\end{array}$ & $\begin{array}{l}\text { high end } \\
\text { mall,seminggu sekali, } \\
\text { tas, sepatu,scarf, } \\
\text { baju,>1juta,cash dan } \\
\text { kartu kredit, } \\
\text { mengutamakan produk } \\
\text { up to date. } \\
\end{array}$ & $\begin{array}{l}\text { Middle class dan high end } \\
\text { mall, setiap minggu, baju, tas, } \\
\text { sepatu, make up, 150ribu s.d } \\
1 \text { juta, cash dan karu kredit, } \\
\text { mengutamakan kenyamanan } \\
\text { dan eksklusifitas. }\end{array}$ \\
\hline $\begin{array}{l}\text { Preferensi } \\
\text { media dan } \\
\text { merk }\end{array}$ & $\begin{array}{l}\text { Charles and Keith, } \\
\text { Mango, Zara, Pull } \\
\text { and Bear, Nine West, } \\
\text { The Executuve. } \\
\text { Mendapatkan } \\
\text { pengetahuan dari } \\
\text { blog dan window } \\
\text { shopping. }\end{array}$ & $\begin{array}{l}\text { Zalora, Zara, Paris } \\
\text { Hilton, Mango. } \\
\text { Mendapatkan } \\
\text { pengetahuan dari } \\
\text { majalah Cosmopolitan, } \\
\text { Laika, } \\
\text { Instagram,browsing } \\
\text { internet. } \\
\end{array}$ & $\begin{array}{l}\text { Andre Valentino, Guess, Kate } \\
\text { Spade, Zara, Coach. } \\
\text { Mendapatkan pengetahuan } \\
\text { dari majalah Lux, } \\
\text { Cosmopolitan, Cleo dan } \\
\text { browsing internet. }\end{array}$ \\
\hline Identitas & $\begin{array}{l}\text { Produk tidak dijual } \\
\text { online, tidak ada } \\
\text { jiplakannya, gaya } \\
\text { berbusana feminin. }\end{array}$ & $\begin{array}{l}\text { Gaya busana } \\
\text { dipengaruhi } \\
\text { lingkungan menengah } \\
\text { ke atas (social } \\
\text { climber), gaya busana } \\
\text { high end } \\
\end{array}$ & $\begin{array}{l}\text { Tidak menyukai barang } \\
\text { diskon dan tidak bermerk, } \\
\text { gaya harus selalu update, } \\
\text { gaya busana casual feminin. }\end{array}$ \\
\hline Peer Group & $\begin{array}{l}\text { Berbelanja dengan } \\
\text { keluarga atau sendiri, } \\
\text { tidak ada pengaruh } \\
\text { lingkungan } \\
\text { pertemanan atau } \\
\text { komunitas. }\end{array}$ & $\begin{array}{l}\text { Berbelanja dengan } \\
\text { teman komunitas } \\
\text { fashion (hijabers } \\
\text { community), } \\
\text { dipengaruhi } \\
\text { lingkungan kerja. }\end{array}$ & $\begin{array}{l}\text { Bebelanja dengan teman, } \\
\text { pacar, atau sendiri, } \\
\text { dipengaruhi komunitas radio } \\
\text { kampus, lingkungan } \\
\text { pertemanan dari SMP-SMA- } \\
\text { kuliah. }\end{array}$ \\
\hline $\begin{array}{l}\text { Expected } \\
\text { Value }\end{array}$ & $\begin{array}{l}\text { Puas ditanya seputar } \\
\text { produk yang dipakai, } \\
\text { senang dipuji orang } \\
\text { lain tentang produk } \\
\text { bermerk yang } \\
\text { dipakai, percaya diri } \\
\text { saat memakai produk } \\
\text { bermerk. }\end{array}$ & $\begin{array}{l}\text { Suka menjadi referensi } \\
\text { fashion diantara teman } \\
\text { kerja (kiblat fashion), } \\
\text { puas ditanya seputar } \\
\text { produk yang dipakai, } \\
\text { percaya diri meningkat } \\
\text { saat orang lain } \\
\text { mengetahui produk } \\
\text { fashion bermerk yang } \\
\text { dipakainya. }\end{array}$ & $\begin{array}{l}\text { Percaya diri, } \\
\text { mempertahankan image, dan } \\
\text { menjadi trendsetter fashion di } \\
\text { kantornya. }\end{array}$ \\
\hline
\end{tabular}



Fashion sebagai sebuah fenomena komunikatif dan kultural yang digunakan oleh suatu kelompok untuk mengonstruksi dan mengomunikasikan identitasnya, karena fashion mempunyai cara nonverbal untuk memproduksi serta mempertukarkan makna dan nilai-nilai yang ingin dikomunikasikan melalui apa yang ditampilkan.

Hal pertama yang menunjukkan identitas mereka terlihat pada produk yang dipakai terutama ekslusifitas produk dan preferensi produk original. Nara sumber 1 memilih produk fashion yang eksklusif. Eksklusifitas produk adalah produk yang diproduksi dalam jumlah terbatas. Sesuatu yang eksklusif baginya adalah yang tidak dijual online karena sering tidak sesuai dengan ekspektasi, harus bermerek dan harus dijual di mall meskipun hanya karet dan jarum pentul. Ia membeli barang yang tidak ada jiplakannya seperti Charles and Keith. Ia tidak memakai Guess, $L V$ dan Hermes karena jiplakannya banyak. Nara sumber 1 menganggap sepatu Nine West mencerminkan dirinya (gue banget) karena produk ini dijual dengan item terbatas dan tidak ada jiplakannya.

Bagi nara sumber 3, eksklusifitas produk terlihat pada pemilihan akan merek tertentu, dimana ia memilih merek Guess dan Andre Valentino dan tidak memakai lagi Charles and Keith. Ia juga tidak menyukai barang diskon, karena itu ia lebih memilih barang-barang mahal. Nara sumber 3 juga memutuskan untuk tidak memakai merk Charles and Keith setelah mencapai karir yang lebih stabil dengan kenaikan gaji yang berulang dan menggangap merk tersebut sudah tidak nyaman untuk dipakai. Hal ini menunjukkan bahwa nara sumber 3 merasa merk Charles \& Keith sudah tidak sesuai lagi dengan level kelas dan status sosialnya saat ini. Sehingga merk tersebut tidak lagi merepresentasikan dirinya dan dianggap barang murahan setelah ia mencapai kematangan finansial.

Selain itu, identitas pekerja muda perempuan bisa dilihat dari gaya busana masing masing yang dipakai oleh ketiga nara sumber tersebut. Nara sumber 1 cenderung memiliki gaya berbusana yang berubah - ubah karena karakteristiknya moody. Kadang ia memiliki gaya busana youth agar terlihat lebih muda dengan memakai celana belel. Tetapi ia kadang juga menyukai gaya busana yang terlihat feminin. Menurutnya, membeli produk fashion bermerek itu dilakukan karena sesuai dengan kelasnya.

Gaya busana nara sumber 2 cenderung high end dan harus fashionable. Latar belakang pekerjaan dengan kelas sosial menengah ke atas mendorongnya memilih produk dengan merek yang terkenal dan mahal. Ia mengharuskan dirinya menggunakan fashion yang berganti- ganti, terbaru, dan unik. Ia juga memakai fashion yang lebih feminim, lebih fashionable dan gaul. Baginya harga tidak pernah menipu. Sedangkan, gaya busana nara sumber 3 cenderung kasual feminin. Lingkungan pekerjaan sebagai Legal Officer yang 
mapan menuntut ia harus terlihat feminin. Sedangkan di luar kantor ia lebih kasual. Ia juga harus selalu up to date dengan perkembangan fashion terkini.

Gaya busana yang digunakan oleh nara sumber menunjukkan bahwa mereka membentuk identitas tertentu melalui merek fashion yang mereka pakai. Nara sumber 1 misalkan lebih menginginkan identitas sebagai anak muda, berkelas (kelas sosial atas), dan feminin. Sedangkan nara sumber 2 lebih menginginkan identitas sebagai kelas sosial atas dan termasuk dalam komunitas yang ia ikuti. Sedangkan nara sumber 3 membangun citra dirinya sebagai seorang atasan di kantornya.

Nilai yang ditukarkan selanjutnya adalah hubungan (relationship) antara nara sumber dengan kelompok disekitarnya (peer group). Dalam penelitian ini, peer group yang dimaksud adalah teman atau kelompok yang berada di sekeliling nara sumber dan dan atau orang yang terkadang menemani nara sumber dalam kegiatan berbelanja fashion bermerk. Pada nara sumber 1 menunjukkan bahwa ia tidak mengharapkan nilai hubungan dari fashion bermerek yang ia pakai. Hal seperti ini sekaligus mengindikasikan adanya superioritas dalam diri nara sumber 1 yang menjadikannya tidak memerlukan hubungan dengan orang-orang di sekitarnya.

Untuk nara sumber 2, keberadaan teman komunitas fashion (hijabers community) menjadi penting karena komunitas tersebut yang menjadi tempat berbagi pengetahuan dan kegemaran barang-barang fashion bermerk. Komunitas ini memungkinkan perempuan yang ingin menggunakan jilbab trendi bisa berkonsultasi mengenai berbagai hal yang berkaitan dengan jilbab, mulai dari cara pemasangan, cara memadu-padankan, mode baju muslim, dan lain-lain. Dengan memiliki barang tertentu yang sesuai dengan ciri komunitasnya, nara sumber 2 merasa diterima dan menjadi bagian dari komunitas tersebut. Teman-teman di dalam komunitas itu pun menjadi referensi utama dalam hal berpenampilan dan barang fashion apa yang harus dimiliki untuk dapat dikenali sebagai anggota dari hijabers community. Selain itu lingkungan kerja kalangan menengah atas dianggap nara sumber 2 menuntutnya berpenampilan seperti mereka, yaitu dengan menggunakan produk fashion bermerek.

Teman-teman semasa Sekolah Menengah dan kuliah merupakan bagian dari peer group nara sumber 3. Ia menyatakan bahwa lingkungan pertemanan yang menyukai barang fashion bermerk menyebabkan ia ikut terbawa menyukai barang-barang tersebut. Selain itu pengaruh komunitas radio kampus yang pernah ia geluti di masa kuliah dengan gaya hidup serba up to date juga menuntut ia untuk menjadi seseorang yang "melek" fashion. Bahkan nara sumber 3 terkadang dapat membeli barang fashion bermerk yang sebenarnya tidak 
terlalu disukai atau dibutuhkannya hanya karena dorongan temannya untuk membeli. Hal seperti ini menunjukkan adanya peer pressuredalam diri nara sumber 3.

Dalam konsumsi fashion bermerek, expected-value muncul sebagai nilai yang mengimingi perempuan dengan harapan-harapan tertentu. Rasa percaya diri, kepuasan diri dan penghargaan dari orang lain merupakan nilai-nilai yang diharapkan dari fashion bermerek. Dari ketiga nara sumber penelitian ini, ditemukan bahwa mereka bersepakat dengan menggunakan produk fashion bermerek akan memberikan rasa percaya diri yang lebih pada dirinya, dan dihargai oleh orang lain dalam pergaulan. Sedangkan kepuasan diri lebih mengarah pada kepuasan telah sanggup membeli menjadi produk fashion bermerek yang harganya mahal, menjadi pusat perhatian dan menjadi sumber perkembangan fashion. Hal ini ditunjukkan oleh nara sumber 1 yang berharap mendapat pujian orang lain atas pakaian yang ia kenakan. Nara sumber 2 bahkan berharap ia akan menjadi trendsetter dilingkungannya dengan menggunakan produk fashion bermerek. Sedangkan nara sumber 3 berharap dengan menggunakan produk fashion bermerek ia akan mempertahankan image-nya sebagai orang yang memiliki jabatan tinggi di kantornya.

\section{Pembahasan Temuan Penelitian}

\section{Nilai-nilai yang ditukarkan dengan merk fashion}

Dalam bingkai pemikiran Marxis, terdapat dua nilai yang ada dalam konsumsi. Pertama, nilai guna (use-value) merupakan nilai pakai yang ada pada produk atau barang yang dibeli. Pakaian memiliki nilai guna menutupi tubuh, melindungi tubuh dari sinar matahari dan berbagai gangguan yang lain. Kedua, nilai tukar (exchange-value) merupakan nilai simbol atau nilai sosial yang direkatkan pada barang tersebut. Pakaian memiliki nilai tukar prestige yang menunjukkan menunjukkan jabatan, pekerjaan maupun kelas sosial. Ketika manusia menyadari adanya nilai tukar yang melekat pada setiap barang, hal ini menunjukkan era simulacra telah mendominasi kehidupan tersebut. Simbol-simbol tersebut berarti telah mengalami duplikasi sehingga tidak tahu lagi mana yang asli dan mana yang hasil duplikasi. Berdasarkan temuan diatas, dapat disampaikan bahwa produk fashion telah mengalami duplikasi sedemikian rupa, sehingga hasil keaslian dan hasil duplikasi menjadi kabur. Ketiga nara sumber tidak bisa lagi membedakan mana yang produk fashion dan mana yang merek fashion. Produk dan merek mengalami silang sengkarut sehingga merek fashion itulah yang dianggap produk. Produk yang digunakan tersebut telah melebur menjadi satu dengan merek. Sehingga produk yang tidak bermerek terkenal dianggap tidak memiliki nilai 
tukar yang sepadan dengan usaha (uang) yang dikeluarkan. Fashion sebagai produk tidak berarti apa-apa tanpa merek terkenal.

Nilai tukar muncul dari adanya duplikasi tersebut, karena setiap simbol yang terduplikasi memunculkan makna baru yang berbeda dengan bentuk aslinya. Fashion bermerek terduplikasi dalam berbagai bentuk, mulai dari iklan luar ruang, iklan di majalah, termasuk dalam artikel di media cetak, iklan audio visual, tayangan fashion, display di berbagai mall dan bentuk-bentuk duplikasi lainnya. Ini berarti ada nilai-nilai yang ditukarkan dengan mengenakan produk fashion bermerek. Identitas diri ditunjukkan dengan fashion yang digunakan. Seperti ungkapan Umberto Eco 'I speak through my cloths', fashion menunjukkan siapa Anda sebenarnya. Perntanyaanya adalah identitas apa yang mereka ditukarkan? Jawabannya dapat dipaparkan sebagai berikut.

Pertama, adalah kelas social. Fashion bermerek secara otomatis dianggap menaikkan pamor dan kelas social pemakainya. Nara sumber 2 bahkan terang-terangan mengatakan tujuannya membeli dan menggunakan fashion bermerek agar menjadi sejajar dengan atasannya yang termasuk kalangan kelas atas. Nara sumber 1 walaupun mengelak mengatakan fashion bermerek untuk menaikkan kelas sosial, tetapi secara implicit ia menunjukkan hal yang sama. Nara sumber 1 tidak ingin fashion yang ia kenakan ada jiplakannya dan dipakai oleh orang lain. Eksklusifitas produk yang menjadi incaran nara sumber 1 cukup menunjukkan ia ingin menjadi orang yang juga eksklusif. Kesan eksklusif tentu bukan ciri kelas sosial bawah, melainkan ciri utama kelas sosial atas.

Kedua, identitas sebagai kelompok sosial tertentu. Tergabung dalam kelompok sosial atau komunitas penggemar fashion merupakan prestige yang luar biasa bagi nara sumber 2 dan nara sumber 3. Komunitas hijabers merupakan komunitas yang diikuti oleh nara sumber 2 dimana ia bergaul dengan orang-orang penggemar fashion. Ia mengatakan bahwa fashion bermerek yang ia kenakan saat ini membantu ia masuk ke dalam komunitas tersebut, sehingga ia mempunyai 'bahan obrolan' dengan teman-teman komunitas. Sedangkan nara sumber 3 mengenakan produk fashion bermerek untuk masuk 'gank'terkenal sewaktu ia di sekolah menengah. Akan menjadi hal yang memalukan jika anggota 'gank' tidak berpakaian modis dan fashionable.Sehingga fashion bermerek yang ia kenakan mempermudah mendapatkan teman sekolah. Dengan demikian fashion bermerek juga ditukarkan dengan relationship atau hubungan pertemanan. Mengenakan fashion bermerek mempermudah menjalin hubungan dengan orang lain dan mendapatkan teman di dalam komunitasnya. Hal ini dialami oleh nara sumber 1 dan nara sumber 2, bahwa mengenakan fashion bermerek dan kepemilikan wawasan tentang dunia fashion dapat menjadi bahan obrolan dengan orang lain. 
Dengan bekal tersebut, bahkan telah menjadikan mereka center of fashion atau tempat bertanya bagi orang-orang yang awam tentang fashion. Seperti bertanya tren fashion terbaru, jenis produk fashion, jenis merek fashion dan tempat member produk fashion tersebut. Terutama ketika menggunakan produk fashion terbaru, ia akan menjadi sumber referensi fashion bagi orang lain. Fashion bermerek dapat menjadi magnet bagi nara sumber untuk menarik orang lain agar menjalin hubungan dengannya.

Pujian juga merupakan nilai yang ditukarkan dengan fashion bermerek. Sebagai center of fashion, mereka tentu akan mendapatkan pujian dan penghargaan dari orang lain. Walaupun sebenarnya pujian tersebut bukan ditujukan kepada nara sumber tetapi lebih ditujukan kepada produk fashion itu sendiri. Ketiga nara sumber mengatakan pujian orang lain terhadap fashion yang mereka kenakan merupakan bayaran mahal atas uang yang keluarkan untuk membeli produk tersebut. Bahkan mereka merasa senang setiap ada orang yang memuji produk fashion yang mereka kenakan. Pujian semacam inilah yang membuat nara sumber puas terhadap produk fashion yang mereka kenakan.Mereka merasa bahwa hanya merekalah yang mampu membeli dan mengenakan produk tersebut. Perasaan puas tersebut muncul ketika mereka mendapatkan apa yang diinginkan dari fashion bermerek.

Dari serangkaian pertukaran nilai tersebut berujung pada rasa percaya diri. Ketiga nara sumber menyatakan bahwa dengan mengenakan fashion bermerek mereka lebih mudah menjalin hubungan pertemanan dan mandapat pujian, sehingga tumbuh rasa percaya diri dalam diri mereka. Rasa percaya diri itulah yang perlahan membawa pada keadaan hiperrealitas. Dimana mereka merasa memiliki power atau kekuasaan menjadi center of fashion dalam kehidupan sehari-harinya.

\section{Hiper-realitas produk fashion bermerek}

Bentuk advance dari simulacra adalah simulacrum, dimana bentuk asli tidak bisa dibedakan lagi. Sehingga bentuk duplikasi itulah yang dianggap asli. Dalam hal ini nilai tukar berubah menjadi nilai yang diharapkan (expected value). Nilai ini diharapkan akan didapatkan konsumen ketika mengkonsumsi produk tersebut. Nilai tersebut muncul dari hasil duplikasi simbol yang kemudian makna itu sendiri yang dianggap sebenarnya.

Seperti pada penjelasan sebelumnya, temuan menunjukkan bahwa nara sumber berharap menjadi perempuan yang berkuasa dengan menggunakan produk fashion bermerek. Ada relasi kekuasaan (power relation) yang terbentuk antara pengguna produk fashion bermerek dengan orang-orang di sekitarnya yang tidak menggunakannya. Bagi pengguna fashion bermerek, mereka merasa lebih berkuasa daripada orang lain karena sanggup membeli produk yang mahal, original dan eksklusif, sedangkan orang lain tidak sanggup. 
Secara penampilan, fashion bermerek juga meningkatkan posisi kelas sosial diantara orangorang disekitarnya. Dengan menggunakan produk fashion berlabel Zara, Mango, dan Guess, akan terlihat berkelas dan lebih tinggi derajatnya daripada perempuan yang menggunakan produk fashion tidak berlabel apapun. Hal inilah yang disebut simulacrum. Duplikasi simbol fashion bermerek menyebabkan realitas semu dianggap realitas sesungguhnya. Akhirnya fashion bermerek tersebut dianggap sebagai produk mewah yang memberikan label kekuasaan kepada pemakainya.

Power inilah yang menjadi hiper-realitas para pengguna produk fashion bermerek. Hubungan kekuasaan yang terjalin bukanlah bentuk power dalam arti sesungguhnya. Karena power yang tercipta berbentuk semu atau pseudo-power. Power tersebut berupa hasil duplikasi simbol fashion bermerek yang mengalami pergeseran dari realitas aslinya sebagai pakaian. Bentuk power yang ada pada nara sumber pun tidak sama. Nara sumber 1 membentuk hiper-realitas power ini berupa superioritas pujian. Ia telah menciptakan realitas sebagai orang yang dipuji dan dihargai karena memiliki gaya busana yang fashionable dan menggunakan produk bermerek. Sehingga pseudo-power yang muncul pada diri nara sumber 1 berupa superioritas (superiority). Ia menganggap dirinya superior dengan menggunakan produk fashion bermerek karena dengan menggunakan produk tersebut ia merasa dihargai, dipuji atas gaya busana dan kecantikannya. Dengan adanya pujian tersebut, ia merasa mendapatkan kepuasan diri dan lebih percaya diri di lingkungan kerja. Padahal dari peer group di sekitarnya tidak ada yang menuntut ia berpenampilan dengan fashion bermerek. Hal ini tentu berbeda dengan nara sumber 2 dan 3 dimana lingkungan kerja dan komunitas menuntut mereka untuk berpenampilan menggunakan produk fashion bermerek.

Sedangkan untuk nara sumber 2, realitas kekuasaan yang ia miliki adalah menjadi kiblat fashion. Dimana ia menjadi trendsetter fashion di komunitasnya. Gaya yang ia sukai dan ciptakan diikuti oleh banyak perempuan. Nara sumber 2 membingkai pseudo-power dalam bentuk trendsetter. Yaitu ia merasa senang dan puas ketika orang lain bertanya kepada dirinya seputar perkembangan fashion dan menjadikannya referensi berbusana. Kekuasaan yang ia inginkan adalah gaya busana yang pakai dapat mempengaruhi dan diikuti gaya busana orang lain.

Adapun nara sumber 3, menciptakan realitas kekuasaan dengan menggunakan fashion bermerek yang ia kenakan untuk meneguhkan posisinya sebagai legal officer senior di kantornya. Power yang dihasilkan dari fashion bermerek lebih bersifat menguatkan dominasi nara sumber 3 secara struktural organisasi (dominator). Sebagai perempuan yang memiliki jabatan dan bawahan, ia merasa harus berpenampilan yang fashionable dan berkelas. 
Penampilan berkelas tersebut diartikulasikan dengan konsumsi produk fashion bermerek, yang mana bawahannya secara finansial tidak sanggup membeli produk tersebut. Sehingga dengan membeli produk fashion bermerek yang harganya mahal, akan semakin memperkuat posisi nara sumber 3 sebagai atasan yang dominan di kantornya.

\section{Penutup}

Hiper-realitas mengacu pada kondisi realitas budaya yangvirtual ataupun artifisial di dalam komunikasi dan konsumsi perempuan pekerja muda. Realitas-realitas ini mengungkung perempuan pekerja muda dengan berbagai bentuk simulasi (penggambaran dengan peniruan). Simulasi inilah yang mencitrakan sebuah realitas yang pada hakikatnya tidak senyata realitas yang sesungguhnya. Realitas yang "tidak sesungguhnya" tetapi dicitrakan sebagai realitas yang mendeterminasi kesadaran "kita" inilah yang disebut dengan realitas semu atau hiperrealitas(hyper-reality).

Fashion bermerek bagi para pekerja muda perempuan di Jakarta dimaknai lebih dari sekedar pemenuhan kebutuhan untuk menutupi dan melindungi tubuh dalam beraktifitassehari-hari. Terdapat kondisi hiper-realitas yang dibangun oleh para pekerja muda perempuan dalam memaknai produk fashion bermerek yang mereka kenakan.

Hiperrealitas pekerja muda perempuan dalam memaknai produk fashion bermerek yang mereka kenakandibentuk secara individu melalui serentetan proses. Mulai dari motivasi, peer group, media habit, shopping habit dan expected value.

Hiper-realitas yang terbentuk berupa pseudo-power, yaitu kekuasaan semu karena menggunakan produk fashion bermerek. Bentuk pseudo-power terbagi 3 menjadi superior, trendsetter dan dominator. Superior memandang fashion bermerek yang dikenakan dapat menciptakan superioritas bagi dirinya. Hal ini dikarenakan dengan menggunakan produk tersebut ia merasa dihargai, dipuji atas gaya busana dan kecantikannya, sehingga merasa mendapatkan kepuasan dan lebih percaya diri di lingkungannya. Padahal dari peer group di sekitarnya tidak ada yang menuntut ia berpenampilan dengan menggunakan fashion bermerek. Sementara trendsetter menganggap dirinya akan merasa senang dan puas ketika orang lain bertanya kepada dirinya seputar perkembangan fashion dan menjadikannya referensi berbusana. Kekuasaan yang ia inginkan adalah gaya busana yang pakai dapat mempengaruhi dan diikuti orang lain. Sedangkan dominator menganggap bahwa dengan membeli produk fashion bermerek yang harganya mahal, akan semakin memperkuat posisinya sebagai atasan yang dominan di kantornya.

Ketiga kategorisasi hiper-realitas yang dibangun oleh para pekerja muda tersebut juga terkait dengan nilai-nilai sosial yang ditukar pekerja perempuan terhadap produk fashion 
bermerek yang dikenakannya. Nilai-nilai tersebut berupa kelas sosial, kelompok sosial atau komunitas, hubungan dengan orang lain, pujian dari orang lain, dan rasa percaya diri.

\section{Daftar Pustaka}

Agustin, Ayu. (2012). Konstruksi dan Representasi Gaya Hidup Muslimah Perkotaan: Studi Kasus pada Hijabers Community di Jakarta. Jakarta: Universitas Indonesia.

Anggraini, Elvira. (2012). Pengalaman Komunikasi Konsumen Wanita dengan Gaya Hidup "Brand Minded". Semarang: Jurusan Ilmu Komunikasi, FISIP, Universitas Diponegoro.

Barnard, Malcolm. (2011). Fashion Sebagai Komunikasi. Yogyakarta: Jalasutra.

Baudrillard, J.P. (1970).La Societe de Consommation, editor: Mike Featherstone, 1998, In The Consumer Society. London: Sage Publication Ltd.

Baudrillard, J.P.(1970). La Societe de Consommation, penerj. Wahyunto, 2009, dalam Masyarakat Konsumsi, cet. ke-3, Yogyakarta: Kreasi Wacana.

Baudrillard, J. P. (1994). Simulacra and Simulation. Michigan: The University of Michigan Press.

Bourdieu, Pierre. (1984). Distinction: A Social Critique of the Judgement of Taste, terj. Dari bahasa Perancis oleh Richard Nice, London: Routlege.

Claik, Jennifer. (1993) The Face Of Fashion: Cultural Studies In Fashion. Routledge: New York.

Eco, Umberto. (1979). Theory of Semiotics. Indiana: University Of Indiana Press.

Faturokhman, Mokh Ronny. 2000. Pola Komunikasi Verbal dan Nonverbal Anak Jalanan d Alun-alun Kota Bandung. Skripsi. Bandung.

Hadi, I. P. (2009). Penelitian Khalayak dalam Perspektif Reception Analysis. SCRIPTURA, $1-7$. 
Haryatmoko. (2010). Dominasi Penuh Muslihat: Akar Kekerasan dan Diskriminasi. Kompas Gramedia: Jakarta.

Hennink, M., Hutter, I., \& Bailey, A. (2011). Qualitative Research Methods. London: Sage Publications.

Hurlock, E.B. (1996). Psikologi Perkembangan Suatu Pendekatan Sepanjang Rentang Kehidupan. Jakarta: Erlangga.

Ibrahim, Idy Subandy.( 2007). Budaya Populer Sebagai Komunikasi. Jalasutra: Yogyakarta.

Littlejohn, S. W. (2002). Theories of Human Communication 7th Edition. California: Wadsworth.

Piliang,Yasraf Amir. (2011). Imagologi dan Gaya Hidup. Yogyakarta: Jalasutra.

Puspita \& Nashori. (2009). Hubungan Antara Kepercayaan Diri Dengan Minat Membeli Barang-Barang Bermerek. Yogyakarta: UII.

Neuman, L. W. (2006). Social Research Methods : Qualitative and Quantitative Approaches 6th Edition. Boston: Pearson.

Noeng Muhadjir. (2000). Metodologi Penelitian Kualitatif. Edisi IV. Yogyakarta: Rake Sarasin.

Nugraha, Rahmadya Putra. (2012). Fashion Sebagai Pencitraan Diri Dan Identitas Budaya. Skripsi.Purwokerto.

Ritzer, G., (2006). The Postmodern Social Theory, penerj. Muhammad Taufik, dalam Teori Sosial Postmodern cet. ke-3, Yogyakarta: Kreasi Wacana.

Savitrie, D. (2008). Pola Perilaku pembelian Produk Fashion. Depok: Universitas Indonesia.

Svendsen, Lars. (2006). Fashion InA Philosophy. Britain:Cromwell Press, Trowbrigde 
Takwin, Bagus. (2006). Habitus: Perlengkapan dan Kerangka Gaya Hidup. Yogyakarta: Jalasutra

Wittasari, A. D. (2008, October 30). Wanita Pekerja Rentan Gila Belanja. Jakarta: Kartini , pp. 68-72.

\section{Laman:}

BrickMarketing. www.brickmarketing.com. http://www.brickmarketing.com/definebranding.htm (accessed March 25, 2013).

Hidayat, M. A. (2008, April 15). Retrieved March 2, 2013, from fordiletante.wordpress.com: http://fordiletante.wordpress.com/2008/04/15/kebudayaan-postmodern-menurut-jeanbaudrillard/

Kemenpora.

HYPERLINK

"http://kemenpora.go.id/pdf/UU\%2040\%20Tahun\%202009.pdf"http://kemenpora.go.id/ pdf/UU 40 Tahun 2009.pdf, (accessed March 25, 2013).

Rema, D. (2013, January 18). Retrieved February 16, 2013, from wolipop.com: http://wolipop.detik.com/read/2013/01/18/180126/2146753/1133/riset-18-gaji-wanitadipakai-untuk-membeli-baju-kerja?w992201835

Tinarbuko, S. (2011, March 20). Retrieved March 2, 2013, from sumbotinarbuko.com: http://sumbotinarbuko.com/teori-semiotika-semiotika-sebagai-ilmu.html

Wuryanta, A. E. (2011, June 15). Retrieved March 3, 2013, from ekawenats.blogspot.com: http://ekawenats.blogspot.com/2011/06/makalah-teori-kritis-simulacra-dan.html 